\title{
Annelik, Söylem ve Iktidar: Eleştirel Bir Tartışma
}

\section{Motherhood, Discourse and Power: A Critical Discussion}

\author{
Meral TIMURTURKAN \\ Burdur Mehmet Akif Ersoy Üniversitesi, Sosyoloji Bölümü, mtimurturkan@mehmetakif.edu.tr
}

\author{
ORCID Numarası|ORCID Numbers: 0000-0002-1505-5544
}

Öz: Bu çalışma; toplumsal, kültürel ve politik yapıların annelik deneyimini şekillendirdiği varsayımından yola çıkarak, anneliğin çeşitli söylemlerin odağında yeniden üretilen ve dönüşen konumuna ilişkin bir tartışma yürütmeyi amaçlamaktadır. Bu anlamda annelik kavramı odağında yürütülen tartışmaları, tarihsel ve kültürel bağlamlarından yola çıkarak kuramsal bir çerçevede ele almak ve anneliğe yüklenen anlamların neler olduğunu anlamak bu çalışmanın ana eksenini oluşturmaktadır. Her dönemin ekonomik, toplumsal ve politik söylemlerinin farklı anneliklerin ortaya çımasına aracılık ettiği ve kadınlık kimliğinin en belirgin rolünün (yas, sınıf, eğitim, ırk ayırt etmeksizin) annelik rolü olduğu gerçeği eleştirel sosyolojik bir tartışmayı gerekli kılmıştır. Annelik her zaman farklı düşünce pratikleri içinde tartışmalı bir konu olarak ele alınmış, kadınlık kimliğinin en önemli belirleyeni olarak da görülmüştür. Kadınların sorumlulukları, aile içi rolleri ve kamusal yaşamdaki ilişkileri bu kimlik etrafında şekillenerek, toplumsal cinsiyetin normatif düzeni oluşturulmaya çalışılmıştır. Bu nedenle annelik, feminist yaklaşımın da çelişkili konularından biri olmuştur. Bir yandan anneliği kadın için bir baskı aracı olarak gören yaklaşımlar, öte yandan kadına özgü farklılıkları ön plana çıkartarak anneliği olumlayan yaklaşımlar feminist düşünce içinde iki farklı çizgide meseleyi ele almaktadır. Bedenin yönetimselliğine işaret eden biyo-politik söylemin de bu tartışmalara eklemlenmesi ile birlikte annelik, önemli bir iktidar alanına dönüşmüştür.

Anahtar Kelimler: Annelik, söylem, iktidar, biyo-politika, feminizm

Abstract: Starting from the assumption that social, cultural and political structures shape the experience of motherhood, this study aims to conduct a discussion on the position of motherhood being reproduced and transformed in the focus of various discourses. In this sense, the main axis of this study to examine the debates carried out in the focus of motherhood from the historical and cultural contexts and to discuss the meanings attributed to motherhood in a theoretical framework. The reality that the economic, social and political discourses of each period mediate the emergence of different motherhoods, and the most prominent role of womanhood identity is the motherhood (regardless of age, class, education race) has made a critical sociological discussion necessary. Motherhood is always approached as a problematic topic in different thought practices, it is also seen as an important determinant of womanhood identity. It is tried to be formed a normative order of gender by shaping women's responsibilities, roles in the family and their relations in the public life. Thus, motherhood is one of the contradictions of feminist approach. On the one hand, approaches that perceive motherhood as a means of oppression for women, and on the other hand, the approaches affirming of motherhood by highlighting differences specific to woman, discuss the issue from two differen perspectives within the feminist thought. With including of bio-political discourse pointing to the body's governmentality to these discussions, motherhood has become an important field of power.

Key Words: Motherhood, Discourse, Power, BioPolitics, Feminism 


\section{GİRIŞ}

Her dönemin kültürel değerleri ve politik anlayışı, toplumsal cinsiyet bakış açısını şekillendirerek, ikili cinsiyet rejimi üzerinden kadınlık ve erkeklik kimliğini inşa etmektedir. Bu süreç aynı zamanda "kadınlık" kimliğinin hem ontolojik hem de toplumsal bir kategori olarak tanımlanmasını kaçınılmaz kılarak, bu kimliği oluşturan kültürel süreçlerin ve tarihsel bağlamların neler olduğunu sorgulamamızı da zorunlu kılar. Bu bağlamda anneliğin; kadınlar için ayırt edici bir özellik olarak süre geldiğini söylemek iddialı olmaz. Bir cinsiyet kategorisi olarak kadınlığı tanımlayan en ayırt edici özellik; annelik rolü ve bu rol etrafında cinsiyetin normatif düzeni içinde konumlanmasıdır. Toplumsal düzenin kabul görmesini sağlayan ve cinsiyetler rejiminin hiyerarşik bir ilişki içinde oluşmasına neden olan farklı ideolojik yapılar, anneliğe ilişkin farklı söylemlerin gelişmesine de kaynaklık etmiştir. Ataerkillik, kapitalizm, biyoloji, teknoloji, tıp ve sosyal yapı gibi kurum ve ideolojiler anneliği biçimlendiren ve kurumsallaştıran unsurlardan bazılardır.

Anneliğin doğal, içgüdüsel bir süreç olduğu düşüncesi, bu kurumlarla desteklenmiş ve uzunca süre hakim bir paradigma olmuştur. Bu paradigmayı tersine çeviren feminist yaklaşımlar, anneliğin kadınlar için doğal bir durum olmadığını tarihe yön veren dinamikler 1şığında kültürel ve sosyal olarak inşa edildiğini savunmuştur (Silva, 2003). Bu bağlamda annelik; feminist hareketin odak noktasını oluşturan güç ve mülkiyet ilişkilerinden, ataerkillik, toplumsal cinsiyet, cinsellik ve ayrımcılık gibi kavramlardan da bağımsız tartışılamaz. Aynı zamanda anneliğin sosyal inşasına yönelik anlamları yeniden düzenleyen veya anneliği bir deneyim olarak olumlayan feminist analizler de konuya farklı açılımlar sunmaktadır. Feminist yaklaşım içinde anneliğin; cinsiyet eşitsizliğinin üretilmesinde, kadınlık kimliğinin ötekileştirilmesinde ve cinsiyet rollerinin dayatılmasında önemli bir araç olduğu tartış1makta, öte yandan annelik dolayımıyla kadınlığa özgü olan farklılıkların, düşünme biçiminin ve deneyiminin önemi ele alınmaktadır. Bu noktada bir kurum olarak ve bir deneyim olarak annelik tartışmaları, anneliğe ilişkin hem kolektif hem de bireysel bakış açısını içererek, anne olmaya, annelik deneyimine ve kadına yönelik toplumsal pratiklerin hangi bağlam içinde örgütlendiğinin de bir göstergesidir. Çünkü bir kurum olarak annelik; toplumsal cinsiyet düzeninde kadın için baskılayıcı bir durum ve süreç olmakta, önceden belirlenmiş kurulu sabitlikler üzerinden kadınların deneyimini şekillendirmektedir. Bir başka ifade ile kadınların annelik deneyimi önceden belirlenmiş bir dizi yaptırım, beklenti ve rollere göre şekillenerek oluşmaktadır. Toplumun kadından beklentilerini içeren bu baskılayıcı süreç aynı zamanda çeşitli iktidarların politikalarında ve uygulamalarında da somut yer bulmaktadır. Dünya genelinde hükümetlerin doğurganlık politikaları, tıbbi şirketlerin kadın bedeni üzerinde önemli endüstri alanları yaratması, kapitalizmin üretim ve tüketim ilişkilerini buna göre biçimlendirmesi bu somut örneklerden bazılarıdır.

Rothman'ın $(1994,2000)$ kavramlarına ve tanımlamalarına başvurarak açıklayabileceğimiz bu süreç; kapitalizm, teknoloji ve ataerkil ideolojinin iş birliğini gerekli kılar. Aynı zamanda farklı iktidar yapılarının annelik ve dolayısıyla kadın bedeni üzerinde nasıl söz sahibi olduğunu da anlamamıza olanak sağlar. Biyo-politika ile açıklayabileceğimiz ve bireylerin tek tek bedenlerine, yaşamlarına, nüfuslara odaklanan bu iktidar türü; kadınların yaşamları, cinsellikleri ve gündelik yaşamları üzerinde düzenleyici ve denetleyici güce dönüşerek ataerkil ideolojinin yeniden üretilmesine de aracılık eder. Bu süreç politik bir takım amaçlara hizmet etmesinin yanı sıra, ekonomik anlamda kadın bedeninin tüketim kültürü içinde önemli bir kâr alanına dönüşmesini de sağlamaktadır. Üreme yetisinden, hamileliğe, doğumdan, çocuk bakımına kadar pek çok alan aynı zamanda tüketim piyasası için paha biçilmez alanlar olarak tanımlanmaya başlanmaktadır. 
$\mathrm{Bu}$ çalışmanın amacı söz konusu tartışmalardan yola çıkarak, annelik kimliğinin çeşitli söylemlerin odağında nasıl yeniden şekillendiğini ve üretildiğini anlamaya çalışmaktır. Yeni anlam dünyalarının yaratılmasına aracılık eden "söylem", anneliğe ilişkin yaratılan anlamların da nasıl dönüştüğünü analiz etmemizi sağlar. Her dönemin toplumsal, ekonomik ve politik söylemlerinin farklı anneliklerin ortaya çıkmasına aracılık ettiği ve kadınlık kimliğinin en belirgin rolünün (yaş, sınıf, eğitim, ırk ayırt etmeksizin) annelik rolü olduğu gerçeği, eleştirel sosyolojik bir tartışmayı gerekli kılmıştır. Nitekim bu çalışma; kadınlık ve annelik arasındaki ilişkiyi tarihsel bağlam içine yerleştirerek, kadının üreme rolü üzerinden toplumsal gerçekliklerin nasıl yaratıldığının ve bunların sosyolojik eleştirisine dayanmaktadır. Dolayısıyla çalı̧̧ma toplumsal ve kültürel söylem, feminist söylem ve biyo-politik söylem olmak üzere üç farklı başlıkta konuyu analiz edecektir. Toplumsal söylem; anneliğin kültürel, ekonomik ve politik bağlamda değişen anlamlarına odaklanmakta ve tarihsel süreç içinde farklı annelik söylemlerinin nasıl geliştiğini tartışmaktadır. Bu söylemler aynı zamanda evrensel, genelgeçer annelik formlarının yaratılmasına aracılık ederek, toplumsal cinsiyet bakış açısını da şekillendirmektedir. Toplumsal söylem, kadınların annelik rolleri ve toplumun yeniden üretim işlevi üzerinde gündelik yaşam pratiklerini şekillendirerek toplumsal iktidarın toplumsal cinsiyet rejimi üzerinde de işlemesine aracılık etmektedir. Bu iktidar alanını eleştiriye açan, toplumsal cinsiyet ilişkilerini ve toplumda süregiden eşitsizliklerin nedenini anlamaya çalışan feminist yaklaşım içinde de annelik önemli bir konu olarak farklı açılardan tartışılmaktadır. Feminist söylem, hem eleştirel bakış açısını desteklemesi hem de farklı bakış açılarını kendi içinde barındırması bakımından söz konusu çalışma için önemli bir analiz noktasıdır. Anneliği iktidar ilişkileri ile düşünmek, aynı zamanda günümüzde iktidarın farklı doğasını işaret etmek için kullanılan biyo-politik iktidarı ve ona içkin olan annelik söylemlerini de tartışmayı zorunlu kılar. Dolayısıyla annelik ve kadın badeni üzerinden ne gibi söylemlerin üretildiği de son başlıkta tartışmaya açılacaktır.

\section{Toplumsal Söylem: Annelik(ler) ve Tarihsel Bağlam}

Birer toplumsal form olarak kabul edilen kadınlık ve erkeklik; biyolojik farklılıkların kültürel dünya içinde anlamlandırılması ve bu farklılıklardan yola çıkılarak hiyerarşik bir düzenin oluşmasıyla anlam kazanır. Cinsiyet, yönettiği bedeni üreten ve düzenleyen normatif bir kategori olarak tahakküm ilişkileriyle açıklanabilir (Butler, 2013). Allan (2004, s. 57) Batı dünyasında "kadının en kalıcı rolünün" annelik rolü olduğunu belirterek, kadınlık- annelik tartışmalarını toplumsal cinsiyet kavramı etrafında şekillendirir. Annelik rolü, toplumsal olarak cinsiyet rolü klişeleri etrafında inşa edilerek; çocuklara ilişkin çeşitli beklentileri içeren görevleri ve sorumlulukları barındırır. Bu durum tarihsel süreç içinde siyasi, sosyal ve kültürel ideolojilerle de yeniden yapılandırılmış ve kurulmuştur. Kadınlık ve annelik kimliğinin birbirinden ayrılmaz bir hakikat içinde sunulması, anneliğin kadınlığa, kadınlığın da anneliğe indirgenmesini sağlayarak, kadınlık kimliğinin doğurganlık üzerinden tanımlanması ve dolayısıyla onun üzerinden işlevsel kılınmasını kaçınılmaz kılar. Bu süreç tarihsel bir kimlik inşasına da dayanarak; farklı bağlam ve tarihselliklerde farklı kadınlıkların ve anneliklerin de tanımlanmasına aracılık eder. Nitekim bu durumun en somut göstergesi her dönemin kendine ait bir annelik söyleminin olmasıdır. Farklı tarihsel ve kültürel dinamikler, farklı annelik söylemlerinin gelişmesine aracılık ederek, bu söylemlerin bazen nasıl çatıştı̆̆ına da tanıklık etmemizi sağlamaktadır. Her dönemin kendine ait annelik tanımı olduğu, özellikle tarihsel dönüşümlerin ve kültürel pratiklerin bu sürece yön verdiği bir çok çalışmada da ortaya konulmaktadır (Badinter; 1992; Gelen, 1994; Forcey, 1994, Thurer, 1994; Hays, 1996; Moore, 2003). Anneliğin tarihsel bağlam içinde anlaşılabileceği fikri; bizi Foucault'nun bilgi-söylem ve iktidar arsındaki ilişkiye götürerek, anneliği bir sosyal yapı olarak ele almamıza imkan tanır. Çünkü söylem toplumsal bir varlık olan insanların eylemlerini şekillendirerek sınırlayabilmekte, kültürel düzen içinde belli politik ve ideolojik amaçlara da hizmet edebilmektedir (Çelik \& Ekşi, 2008, s. 106). Dolaysıyla annelik; tahakküm ve kendilik teknolojisinin iç içe geçtiği bir söylem alanında anlam kazanır 
(Tekelioğlu, 1999, s. 19). Burada söylem, bir konuyu belirli bir biçimde topluca inşa eden bir grup "anlam, imge ve ifadeler" olarak anlaşılabilir. Anneliğin sosyal bir yapı olarak incelenmesine zemin hazırlar ve belirli bir bilgi formu üreten söylemsel oluşumlar tarafindan nasıl çerçevelendirildiğini anlamamızı sağlar (Garwood, 2014, s. 20). Kültürel düzen içinde söylem ve etkileşim bağlamları, anneliği düzenlenebilen ve denetime açı bir form olarak kurar.

Anneliğin tarihini irdeleyen çalışmalar farklı zamanlarda ve kültürlerde aileye, kadına ve çocuğa olan bakış açısından yola çıkarak tartışmalarını şekillendirirler. Örneğin Antik Dönem‘ den Klasik Dönem'e kadar olan süreç incelendiğinde evliliğin, üremenin ve aile hayatının önemli olduğu görülmektedir. Kadının toplumsal konumu ataerkil düzen içinde daha aşağı konumda iken, din, felsefe, kültürel ve tıbbi inançlar kadınların yaşamını ve özellikle anneliklerini etkileyen ve tanımlayan söylemler etrafında konuya dâhil olurlar. Bu dönemin belirgin özelliklerinden biri de bebek ölümlülük oranın yüksek olması ve bunun annelik üzerinde yarattığı etkidir. Anneler seçilmiş olarak gördükleri çocuklarını büyütmek ve ailelerine, ülkelerine başarılı birer vatandaş yetiştirmek adına ayrı bir çabaya girmişlerdir. Çoğu toplumda kadınların rolü, bir eş ve anne olarak ailesini, evini idare etmek ve çocukları yetiştirmek olarak tanımlanmaktadır (Trevino, 2010, s. 489). Orta Çağ'da ise baskın bir şekilde batıl inançların ve dinî değerlerin annelik, çocuk yetiştirme pratikleri ve gündelik yaşam üzerinde etkili olduğu tartışılmaktadır (Trevino, 2010, s. 492-493). Annelik tarihini irdeleyecek bir çalışmada, aynı zamanda anneliğin bir kurum olarak nasıl şekillendiği ve ortaya çıktığı da göz ardı edilmemelidir. Smart (2003, s. 44) anneliğin kurumsal bir olgu olarak ele alınmasının sanıldığı kadar eski bir tarihe sahip olmadığını, geç modernite olarak tanımladığı 19. Yüzyılın ortalarında ortaya çıktığını ifade etmiştir. Bu dönemden önce anneliğin hukuksal bir zemine dayanmadığını ifade eden Smart'a göre yasal bir statüsü olan baba; çocuğun soyadını, dinini ve ikametgâhını belirlemekteydi. Uygulamada evlenmemiş kadın çocuğunun bakımından sorumlu tutulsa da o dönemde babasız çocuk hukuksal anlamda kimseye ait değildi.

Farklı dönemlerin teknolojik, ekonomik, kültürel ve politik durumunun annelik pratiklerini ve toplumsal bakış açısını nasıl şekillendirdiğini tarihsel dönemlere ayırarak analize girişen Thurer'a göre (1994) eski çağlarda insanoğlunun eylemlerine dürtüleri yön vermekteydi ve bu durum annelik pratiklerine de yansımaktaydı. Bu dönem aynı zamanda anneliğin düzenlemeye tabi tutulmadığ kurallar ve toplumsal yaptırımlar etrafında şekillenmediği, doğallığın hâkim olduğu bir dönemdir. Bu dönemin annelerini doğal veya içgüdüsel anne olarak tanımlayan Thurer, aynı zamanda kadınların ve anneliğin yüceltildiğini söyler. Tarihin başlangıcıyla "büyük-yüce" annelik miti yıkılmış, klasik dönemde ise ikincil konuma sahip olan kadınlar ve seçilmiş çocuklara bakmakla yükümlü "narsist anne"ler toplumda kabul görmüştür. Orta Çağ dönemi'nin anneliğine ilişkin toplumsal ve kültürel kodları ise daha çok din ve batıl inançlar etrafında şekillenmiş, erkekler toplumda güç ve iktidar ilişkilerinin baş aktörü iken, kadınlar eş ve annelik rolü etrafında gündelik faaliyetlerini ve çocuk yetiştirme görevlerini sürdürmekteydi. Evli kadınlardan temel beklenti, çocuk doğurma ve annelik görevini en iyi şekilde yerine getirmeleriydi (Trevino, 2010, s. 493). Anneye biçilen misyon ve sorumluklar bazen biçim değiştirse de kadınlar; çocuğun temel bakımından sorumlu olan ve iyi bir vatandaş yetiştirmenin ahlaki sorumluğunu üstlenen kişiler olmaya devam etmiştir. Nitekim modern dönemde de anneliğe ilişkin toplumsal beklentinin benzer şekilde oluştuğu görülmüş ve bilimsel söylemin annelik üzerinde etkisi tartışılmıştır. "Bilimsel" ve "empatik" anne gibi kavramlar bu dönemde yaşanan gelişmeler ışı̆̆ında tanımlanmış ve annelik; evrensel, genelgeçer sınırları çizilebilen bir olgu olarak görülmüştür.

Annelik deneyimi önemli bir bilgi kaynağı olmasına rağmen, özellikle hamilelik ve doğum gibi süreçlerde uzmanların desteği ve bilgisi bir ihtiyaca dönüştügü görülmektedir. Bununla birlikte, tıbbi sistem temsilcilerinin bilgi ve bakım kaynağının meşrulaşması ile birlikte kadınların deneyimleri ve 
etkinliklerinin görmezden gelinmeye başlandığı ifade edilmektedir (Porter, 2010, s. 505-506). Çocuğu için en doğru kararı veren, psikolojisini düşünen, çocuk büyütmenin bilimsel sınırlarını bilen anneler; toplumun takdir ettiği anneler hâline gelmiştir (Thurer, 1994). Bu süreçte annelik yeni bir uzmanlık alanı olarak tanımlanmakta ve kadınlar piyasanın en önemli müşterisine dönüştürülmektedir. Annelik rolleri bağlamında da tartışmaya açılan bu süreç, aynı zamanda toplumun kadından beklentilerini içerecek yeni sorumluluk alanlarının belirlenmesinde etkili olmaktadır. Bu beklentilerin kadınlar ve çocuklar üzerinde nasıl baskılayıcı olduğunu "Momism" kavramıyla tartışan Wylie'ye göre; bu yeni "anneler" boğucu, aşırı korumacı ve çocuklarına yatırım yapan annelerdir (aktaran: Douglas \& Michaels 2004, s. 4-5). Bu yeni annelik anlayışı Hays'ın (1996) "yoğun annelik" kavramsallaştırılması ile tartışılmış, çocuğun bakımından sorumlu olan, istek ve arzularını öncelikli tutan, kendini çocuğa adayan bir annelik formu çizilmiştir. Annenin her koşulda ve durumda çocuğu ile ilgilenmesi, sevgi ve şefkat gibi duyguları göstermesi ve tüm zamanını ona harcaması gerektiği düşüncesi yoğun annelik ideolojisi içinde öncelikli bir yere sahiptir. Başlangıçta beyaz orta sınıf anneleri için önemli bir ideolojiye dönüşen bu yeni annelik akımı daha sonra her sınıfta ve her konumda olan kadınlar için önemli bir forma dönüşerek egemen ideoloji hâline gelmiştir. Böylelikle mükemmel annenin de sinırları çizilerek, kadının öncelikli görevinin annelik rolü olduğu ve bu rolün belli ölçütler ile daha ideal kılınacağı benimsenmektedir. Kadının sahip oluğu koşullar ne olursa olsun "iyi” bir anne olmak için ayrı bir performans sergilemesi gerekmekte ve çocuğunun her türlü isteklerine cevap vermek zorundadır. Çocuk merkezli bir ebeveynlik olarak da tanımlanan yoğun annelik söylemi, ataerkil ideolojinin kadının üzerinde baskı kurmasının meşrulaştırıldığı bir başka aracı olduğu da tartışmaya açık bir konudur. Çünkü kadının annelik rolü ve bu rolü nasıl yerine getirdiği toplumsal gözetim teknikleri ve başkalarının dolaylı bakışları ile de ölçülebilir bir hâl alır. Sosyal kurumlar, eğitim kurumundan (öğretmenler ve diğer eğitimciler), sağlık kurumuna (doktorlar ve diğer sağlık çalışanları) mükemmel, başarılı ve sağlıklı çocuk yetiştirmenin ölçütlerini sürekli çocuğun bakımından sorumlu tutulan anneye hatırlatılarak onlar üzerinden baskı ve stres yaratabilmektedir (Henderson al et., s. 235). Toplumun her daim anneden beklentisinin olmasi ve iyi annenin sınırlarının çizilmeye çalışılmasının aynı zamanda kadınlarda suçluluk, endişe, stres, zihinsel sağlık problemlerine ve yetersizlik duygularına yol açabildiği de tartışılmaktadır (Uzogara, 2015, s. 67). Özellikle egemen ideolojinin yayılmasına aracılık eden medya, bu stres ve baskının önemli bir aktörü haline gelerek, "ideal" annenin yaratılmasına da kaynaklık etmektedir (Douglas \& Michaels, 2004: 5). "İdeal”, "yoğun" veya "annecilik" olarak tanımlanan yeni annelik formlarının toplumsal katmanda hangi grup tarafından benimsendiği ve uygulandığı da önemli bir sorunsal olarak tartışılmaktadır. Çünkü başlangıçta sınıfsal bir niteliğe bürünen bu ideolojinin, daha sonraları egemen ideolojiye dönüşerek tüm kadınlar için baskılayıcı ve kapsayıcı olduğu da görülmektedir.

Nitekim Badinter'in (2015) "Kadınlık mı? Annelik mi" adlı çalışması tam da anneliğin toplumsal ve kültürel görünümleri üzerine ayrıntılı bir tartışmayı içerir. Badinter’e göre (2015, s. 115) bir dönem kadının toplumsal konumu annelik görevinin ne kadar iyi yerine getirdiği üzerinden ölçülerek, ona sosyal ve siyasal haklar verilmiştir. Annelik sevgisi altında inşa edilen bu süreç; kadının çocuğuna iyi bakması, tüm sevgisini vermesi, emzirmesi ve kendini adaması fikri üzerinden işleyerek anlam kazanmıştır. Özellikle biyolojik bakış açısının temelini oluşturan anneliğin içgüdüsel olduğu düşüncesi ve bu düşünceyi kanıtlamaya çalışan çalışmaların yayınlaması da kadının toplumsal konumunu belirlemiştir. Kadının toplumsal statüsü açısından annelik önemli işleve sahip olmakta, kadınlık kimliği bu biyolojik işlev ve rol üzerinden kurulmaktadır. Bu durumun en somut göstergesi özellikle çocuğu olan kadınların diğer bütün kimliklerinden önce annelik kimliği üzerinden tanımlanması ve diğer kimliklerin buna eklemlenmesidir (Vincent, 2010, s. 110). Bir başka ifade ile çocuğu olan kadın ilkin anne olarak tanımlanır; çalışan anne; yönetici anne; çalışmayan anne gibi kimlikler buna eklemlenerek kadınlık kimliği pekiştirilir. Kadının kamusal yaşamda yer alma biçimini etkileyen bu kimlik, çoğu zaman kadının çalışma yaşamına katılımının önünde bir engel olarak da 
görülmektedir. 2. Dünya Savaşı'ndan sonra beyaz, eğitimli, orta ve üst sınıftan oluşan kadınlar arasında kadınlara yönelik bu hegemonik bakış açısı hâkim olmuş, çalışmayan tam zamanlı çocuğuna bakan annelik söylemi etkili olmuştur (Moore, 2003, s. 57). Bu egemen söylem ikinci dalga feminizmin etkisi ile tartışmaya açılmış, toplumsal cinsiyet devrimi ile birlikte ev dışında çalışan anne miti güçlenmeye başlamıştır.

Kadınların kamusal yaşamda ve özellikle ücretli emek içinde artan oranda yer almasını sağlayan bu devrim, aynı zamanda erkeklerin ev içi rollere ve özellikle çocuğun bakımına yönelik faaliyetlere daha çok katılım sağlayacağı beklentisini içermekteydi. Bir toplumsal değişimin yaşandığı gerçeği feminist düşünürler ve araştırmacılar tarafından kabul görse de, hâlâ kadınların aktif olarak daha fazla sorumluluk üstendikleri tartışılmaktadır (Raley et. al., 2012, s. 1422; Mattingly \& Bianchi, 2003; Hochschild \& Machung, 1989; Gerson, 2010). Dow'un aktardığına göre bütün bu anneliği tanımlayan unsurlar aynı zamanda hegemonik bir veri seti olarak da tartışılmış, anneliğin birinci sorumluğunun çocuk doğurmak ve ona bakmak, babanın ise gelir getirmek olduğu fikri sanayileşmenin ilk yıllarından itibaren egemen olmuştur. Yapılan hegemonik tanımlanmaya anneliğin kendi kendine yetecek bir çekirdek aile içinde gerçekleştiği ve istihdamın anneliğin doğası ile çatışacağı görüşü de eklemlenerek; çalışmayan, çocuğuna bakan ve heteroseksist bir annelik imgesi kabul görülmüştür (Dow, 2016, s. 180181). Bu ideal formlar, anneliğin de belli hiyerarşiler ışı̆̆ında katmanlaşmasına neden olmakta ve doğal olarak bu formun dışında kalan bir öteki anne grubu yaratılmaktadır. Genel olarak "genç anneler, yaşlı anneler, bekar anneler ve lezbiyen anneler" in bu hiyerarşinin alt katmanlarında olduğu düşünülmektedir (Johnston\& Swanson, 2003, s. 22; Arendell, 2000, s. 1195). Sabit tanımlanacak, kültürler arası evrensel bir olgu olmayan annelik, belli bir tarihi olan, değişmiş ve değişebilen, yeniden tanımlanacak bir olgudur (Smart, 1996, s. 37). Nitekim farklı koşullar ve dönemler içinde farklı anneliklerin olduğu tartışması bu düşünceyi doğrular nitelikte olup, tek sabit bir annelik kategorisi ve formundan bahsedilemeyeceği gerçeğini de bize hatırlatır.

\section{Feminist Söylem ve Annelik(ler)}

Kadınlık kimliğini oluşturan toplumsal kodların ve ideolojilerin neler olduğuna ilişkin tartışma toplumsal cinsiyet çalışmalarının odak noktasını oluşturmaktadır. Aynı zamanda bu tartışma, feminist düşünürler tarafından cinsiyet düzenini, toplumsal cinsiyet eşitsizliklerinin nedenini anlamak ve kadının konumunu güçlendirmek adına geliştirilecek politikalar için önemli görülmektedir. Toplumsal düzenin eril bir düzen olduğu ve bu düzenin erkek lehine işlediğini savunan feminist yaklaşım, başlangıçta kamusal eşitlik fikrine odaklanırken, değişen toplumsal dinamikler ve yasal düzenlemeler ile birlikte ataerkillik, toplumsal cinsiyet ve aileye odaklanmış eşitsizliğin nedenlerine ve sonuçlarını açıklamaya çalışmışlardır. Dolayısıyla feminist yaklaşım; kadınlığın ve ona içkin olan biyolojik süreçlerin doğal bir kategori olmadığını toplumsal, politik ve kültürel pratikler tarafından oluşturulduğunu tartışmaktadır. Bu bakış açısı kadınlık kimliğinin en önemli belirleyenine dönüşen anneliğe ilişkin çözümlemelere de yansımıştır. Bu anlamda feminist bakış açıları anneliğin kadınlar için doğal olmadığını, tarihsel, kültürel ve sosyal olarak inşa edildiklerini savunmuşlardır (Silva, s. 1). Kadının toplumsal konumunu biyolojik özelliklerine bağlayan kuramların reddine dayanan bu görüş, aynı zamanda toplumsal ve kültürel pratiklerin kadını nasıl dezavantajlı konuma ittiğinin analizine dayanır ve bu analize dâhil edilen en önemli konuların başında kadının rolleri, aile içi sorumlulukları ve üreme yetisi gelmektedir.

Kadınların, üreme ve çocuk yetiştirmeden sorumlu olması ve aile içi diğer rolleri üstlenmesi "çifte yük" olarak tanımlanmakta ve bu yük ekonomik, sosyal ve kültürel hayata katılımlarını sinırlandırdığı için eleştirilmektedir (Allen, 2005, s. 1). 1970'lerde Ann Oakley'in yaptığ çalışma anneliğe ilişkin bakış açsının toplumsal düzlemde nasıl kurulduğunu anlamamıza olanak tanımaktadır (Glenn, 1994, s. 9) . Söz konusu çalışmasında anneliğe ilişkin toplumda var olan üç temel inanışın neler 
olduğunu ve bunların kimlik inşasında önemli bir dinamiğe nasıl dönüştüğünü de tartışmaktadır. "Tüm kadınların anne olması gerektiğine", "tüm annelerin çocuklarına ihtiyacı olduğuna" ve "tüm çocukların da annelerine ihtiyacı duyduğuna" dair inanışın toplumsal düzlemde önemli bir yere sahip olduğu ele alınmaktadır. Kadınların anne olmaya yönelik ayrı bir çaba içine girmelerine neden olan bu bakış açıları, kadınlığın annelik üzerinde tanımlanmasını ve işlevsel kılınmasını da sağlamaktadır.

“Anneliğin Yapısökümü” adlı çalışmasının başında Smart 'ın (1996, s. 37) da dile getirdiği gibi annelik, doğal bir durum olmayıp; biyolojik düzlemde cinsiyet farklılıklarının ve heteroseksist cinsel aktivitenin doğal bir sonucu olarak kabul edilen bir durumdur. Bu kurum kadınların üreme kapasitelerini tarihsel olarak tanımlamak ve sınırlandırmak için kullanıldığından, annelik kadınlar üzerindeki baskının önemli bir kaynağı olarak da görülmektedir (O’Reilly \& Porter, 2005, s. 2.). İkinci dalga feminizm içinde anneliğe ilişkin yürütülen bu tartışmalar önemli bir yer tutmuş, esas itibariyle annelik, cinsellik, beden, kürtaj hakk1, ataerkillik ve toplumsal cinsiyet gibi önemli kavramlar; kilit kavramlar olarak toplumsal cinsiyet düzenini açıklamak için kullanılmıştır. "Özel olan politiktir" söylemi ile cinsiyete dayalı kamusal ve özel alan ayrımına karşı çıkarak, her iki cins için farklıklara dayanan bir politik mücadele yürütmüşlerdir (Hançer, 2018, s. 178). Ev içi rollerin, sorumlukların, çocuk bakımının ve özel alana ait görülen diğer "mahrem" ilişkilerin aslında kamusal alan ile yakından ilişkili olduğu, bütün bunların söz konusu toplumdaki politik sistemden, söylemlerden ve kültürel düzenden bağımsız düşünülmeyeceği; ikinci dalga feminist grup için önemli bir paradigmaya dönüşmektedir. Bu paradigma kadın bedeni üzerinde yürütülecek politikaların önemli nedeni sayılabilecek "anneliğe" ve dolayısıyla aileye eleştirel yaklaşmaktadır.

Ailenin, çocuğu ve kadını baskı altına alan bir yapı olması ve kadını çocuk doğurma yetisinden dolayı ayrı bir tür olarak tanımlaması buna örnek olarak gösterilir. İkinci dalga feminizm için önemli açılımlar sunan Simon de Beauvoir ise kadınların erkekler ile eşit konumda olmasının önündeki engellerden birinin kadının annelik rolü olduğunu söyleyerek aynı zamanda bu rolün kadını ötekileştirmenin bir nedeni olduğunu da savunmaktadır. Anneliğin kadınlığa içkin olan doğal bir yazgı olduğu düşünülmekte ve bu yazgının tüm sosyal ilişkileri belirleyen önemli bir etkene dönüştüğü ifade edilmektedir (Neyer \& Bernardi, 2011, s. 3). Radikal feministlerin yer aldığ bu grup içinde Juliet Mitchell, Shulamith Firestone, Kate Millet gibi feminist düşünürler bir kurum olarak ailenin kadını nasıl baskı altına aldığını, sınırladığını ve eşitsiz bir ilişkinin öznesi hâline getirdiğini tartışmışlardır. Millet'e göre (1989, s. 60) ataerkil toplum, kadın ve erkek arasındaki ilişkiyi bir iktidar ilişkisi olarak kurmakta, egemen konuma erkeği, tabi konuma kadını yerleştirmeye çalışmaktadır. Bu durum toplumsal kurumlar tarafından pekiştirilerek yeniden üretilmekte ve özellikle kadına yüklediği roller bağlamında ailenin, ataerkil toplumun bir prototipi olduğu Millet tarafından ifade edilmektedir. Aile, devlet ve toplum birbiri ile işbirliği içinde ataerkil düzenin sürdürülmesine aracılık eden en temel ataerkil kurumlar olarak işlev görmekte ve bu ataerkil kurumların sürdürülmesine zaman zaman dinî söylemler de yardım ederek toplumda kadın ve erkeğin konumunun nasıl olması gerektiğini belirlemektedirler. Hangi toplumsal düzen içinde olursa olsun bu ataerkil bakış açılarının kadın için sınırlayıcı ve baskıcı olduğunu söyleyen Firestone'a göre (1993) kadının psikolojisi, toplumsal yaşamı ve iş bölümü, ataerkil ideolojinin dayattığı bu baskılardan doğrudan etkilenmektedir. Biyolojik aile kavramının kadınların yaşantısı üzerinde kısıtlayıc1, baskılayıcı ve bağımlı kılıcı bir etkiye sahip olduğunu tartışan feminist düşünür, aynı zamanda tarih boyunca kadınların nasıl biyolojik yapıların tutsağı haline getirilerek, doğum, acılı sancılar, emzirme ve çocuk bakımı gibi nedenlerden ötürü toplumun diğer üyelerine özellikle erkeklere bağımlı kılındığını tartışmaktadır. Biyolojik yeniden üretimi ve anneliği kadınların ezilmesinin ardında önemli etkenler olarak gösteren Mitchell de konuya ilişkin eleştirel radikal bir duruş sergilemektedir. Kadınların ezilmesinin ardında biyolojik yeniden üretim ve çocuk doğurma işinin yabancılaştırıcı etkisi, kadınların üreme sürecine müdahaleden yoksun olması, cinsellik üzerindeki denetimden yoksunluk ve 
çocukların toplumsallaşmasındaki rolü yatmaktadır (Donovan, 2007, s. 163). Böylelikle Mitchell de diğer radikal feminist düşünürler gibi aileye ve anneliğe odaklanarak, toplumsal cinsiyet eşitsizliği ve kadının ezilmesi üzerine söylemler geliştirmektedir.

Patriarka ve kadının üreme işlevi, cinsiyete dayalı iş bölümüne yol açarak toplumsal cinsiyet ayrımcılığının da en temel nedeni olarak görülmektedir. Radikal feminist grup için ataerkil sistemin dayattığı baskıdan kurtulmanın yollarından biri; kadın bedeni, cinsellik, annelik, duygulanımlar gibi kadına has öznellikleri ve ona yüklenen anlamları yerinden oynatarak, erkek kültürünün yerine geçecek bir kadın kültürü yaratmaktır (Bozok, 2018, s. 106). Buradaki temel sorunsal aslında Simon de Beauvoir ile başlayan anatomin, yazgıya nasıl dönüştüğ̈ ve bu yazgıya bir meydan okuma çabasının ikinci dalga feminizm içinde nasıl tartışıldığıdır. Bu tartışmalar farklı ideolojik kollara ayrılan ve toplumsal cinsiyet eşitsizliğinin nedenini farklı yapılarda arayan tüm feminist yaklaşımlar içinde yer almakta ve özellikle toplumsal iş bölümündeki eşitsizliğin nedenleri irdelenmektir. Nitekim Marksist feminizm için kapitalizm; toplumsal eşitsizlikleri ve toplumsal cinsiyete dayalı eşitsizlikleri açıklamak için kullanılan kilit bir kavram olmuş ve esasen ev içi emek (çocuk bakımı, annelik, aile içi diğer sorumluluklar, ev işi) kapitalist sistemin yarattığı sömürü düzenine tabi olmuştur. Eşitsizliğin nedeninin hem ataerkillik hem de kapitalizm olduğunu ve bu ikisinin birlikte tartışılması gerektiğini söyleyen sosyalist feministler, ev içi rolleri, annelik, çocuk bakımına ilişkin sorumlulukları önemli konular olarak gömmektedir (Bozok, 2018, s. 106). Donovan (2007) Chodorow'un "Annelik, Erkek Egemenliği ve Kapitalizm" adlı çalışmasından hareketle; kapitalizmin kamusal ve özel alan arasındaki ayrımı derinleştirerek, toplumsal üretim alanının nasıl evden koparıldığını tartışmaktadır. İşçilerin ideolojik olarak işlevsel olmaları açısından kapitalist üretim sistemi için yeniden üretilir ve çocuk bakımı da bu sürecin bir parçası olmaktadır. Kadının ev içi emeği, ücrete tabi olmadığından ve sevgiye dayalı emek olarak görülmesinden dolayı değersizleştirilmektedir. Anne olan kadınların, işçilerin kapitalist sistem için hem fiziksel hem de duygusal olarak yeniden üretilmelerine katkıda bulunduğu tartışılmaktadır (Donovan, 2007, s. 162). Kadınlar çalışma yaşamında; hem kapitalist sistemin doğasından kaynaklı sömürülmekte, hem de ataerkil sitemden dolayı aile içi rolleri yerine getirmek durumunda kalmaktadır. Bu durum daha önce de tartışıldığı gibi çifte yük kavramı ile açıklanarak, kadınların ikili bir yapı içinde nasıl ayrımcılığa maruz kaldıklarıyla yakından ilişkilidir.

Anneliği kadın için bir baskı aracı olarak gören yaklaşımların aksine anneliği olumlayan, kadınlar için birleştirici bir unsur olarak gören bakış açısı 1980'lerden sonra gelişerek annelik tartışmalarına yeni açılımlar getirmiştir. Bu bağlamda anneliğe ilişkin tartışmalarda iki farklı retorik etrafında şekillenmiş, bir yandan kadını ötekileştirmenin ve cinsiyet ayrımcılığının nedeni olarak görülen "bir kurum olarak annelik", öte yandan kadın olma hallerinin yani kadına içkin farklılıkların olumlanmasına dayanan "annelik" fikri benimsenmiştir. Anneliğe ilişkin yapılan tartışmalara önemli açılımlar getiren Ruddick'e göre (1980) anne olmak kadına farklı bir bakış açısı kazandırarak düşünme biçimini etkilemektedir. Bu noktada o da anneliği olumlayarak kadını daha güçlü kıldığını ifade etmekte ve kadınların toplumun yeniden üretim sürecinin baş aktörü olduğunu söylemektedir. Anneliğe ait ahlâki, politik muhakemeyi ve eylemi ifade eden anneliğe özgü düşünme biçimi, doğuştan gelen biyolojik, değişmez ve bedensel bir tasarım olmayıp, insanların yaşadığı pratiklerin ve deneyimin sonucu olarak belli düşünme ve görme biçiminin bir ürünüdür. Yaşamsal deneyimin ürünü olan bu düşünme biçimi toplumsal beklentinin anneler üzerinde yarattı̆g 1 bir etkinin ürünü olarak da ortaya çıkmaktadır. Nitekim kadınların potansiyel anneler olarak belli bir dünya içinde hapsedilmeleri ve çocukların bakımından sorumlu tutulmalarından dolayı yaşamı korumaya, insan yetiştirmeye ve barışı sürdürmeye yönelik toplumsal değerlere karşı ahlâki bir bağl1lık geliştirmektedirler (Hughes, 2009, s. 11). Öte yandan annelik kadınlar için belli zorlukları içinde barındırdığından, ataerkil ideolojinin hakim olduğu dünyada kadınlar, sürekli bir mücadele alanı içinde yer almak zorundadır. Kadının anneliğe 
ilişkin bakış açısını ve annelik deneyimini şekillendiren en önemli unsurlardan biri içinde yaşadığı toplumsal düzeni içselleştirme biçimidir.

Anneliğin kadının toplumsal ve bireysel dünyası içinde önemli bir yere sahip olduğunu ifade eden ve anneliği Ruddick gibi olumlayan Rich'e göre (1995); anneliğin bir "kurum" ve bir "deneyim" olarak iki farklı görünümü vardır ve bunlar kadınların tüm sosyal yaşamını şekillendirmektedir. Kendi annelik deneyimden yola çıkarak yazdığı çalışmasında, kurum olarak anneliğin baskılayıcı olduğunu ve kadınlar için anneliği mutlak olmazsa olmaz, doğal, biyolojik ve içgüdüsel kabul edildiğini ifade etmektedir. Annelik sevgisi, kadınlar için mutlak ve evrensel bir duygu olarak sunulmakta, diğer bütün duyguları bastırdığı tartışılmaktadır. Ataerkil ideolojinin kurumsal baskısı annelik üzerinden de işleyerek, kadınlar için kısıtlayıcı bir duruma dönüştüğünü ifade eden Rich (1995) için asıl önemli olan annelik deneyimidir. Annelik kurumu, annelik deneyimi üzerinden baskılayıcı bir mekanizma gibi işleyerek, kadının yaşam biçimini etkilemektedir. Çünkü kurum olarak annelik; kadının cinsiyet rollerini, anneliği nasıl yaşaması gerektiğini, kendi cinsiyetine yönelik beklentilerini içeren önceden belirlenmiş bir sosyal düzenin dayatmasını içerir.

Bu noktada anneliğin sadece biyolojik bir durum olmadığını özellikle toplumsal dinamiklerin ve kültürel pratiklerin bu olgu üzerinde önemli etkiye sahip olduğunu ifade eden Chodorow'a (1999) göre, kadınlar çocuğun bakımından sorumlu tutulan temel kişiler olarak görülmekte, biyolojik annenin yokluğunda bile başka kadınların annenin sorumluluk ve görevlerini üstlendiklerini belirtmektedir. Annelik üzerinden kadın olma hâlinin ön plana çıkartılarak baş tacı edilmesini eleştiren Fransız feminist düşünür Kristeva'ya göre; kadın olma hâlleri ve kadın gücü düşüncesi üzerinden yeni bir din yaratılarak, genel bir kadınlık kategorisi adı altında ona ait özellikler, farklılıklar ve özerklikler yok edilmektedir. Aynı zamanda anne mitinin psikosembolik düzende her şeyin çözümü olarak görülmesini de tehlikeli bulan Kristeva; yeni bir anlayışın kapısını aralayarak yeni kadınlık nosyonu oluşturmaya çalışmaktadır. $\mathrm{Bu}$ nosyon, kadınlığın genelgeçer evrensel bir kategori olmadığını, her kadına has kabul edilebilecek farklılıkların, özgünlüklerin ve özerkliğin olduğunu kabul eden ve üçüncü dalga feminist anlayışın felsefesini oluşturacak bir nosyondur. Her kadının içinde bulunduğu tekil durumlar ve her tekil kadının kendine has özel durumları vardır (Durudoğan, 2007, s. 60-61). Böylelikle anneliğin tek bir değişken etrafında açıklanmayacağı; evrenselleştirici, genelleştirici ve özcü bir bakış açısı ile tartışılmayacak kadar geniş bir durum olduğu ve içinde farklılıkları da barındırdığ gerçeği kabul görmeye başladı. Yakın zamanda yapılan çalışmalar, annenin ve anne olmanın deneyimlerinin ırk, etnisite, kimlik ve sınıf ayrımlarına göre farklılaştı̆ıııın altını çizmiştir (Moore, 2003; Glenn, 1994; Collins, 1994). Annelik deneyimi, yaşamlarındaki diğer farklılıklara rağmen, genellikle kadınlar arasında ortak bir bağ olarak sunulmaktadır (Vincent, 2010, s. 118). Bu noktada Bora'nın (2005, s. 22) kadınlığın bir durum değil bir süreç olduğunu ve tamamlanmamış bir kimlik olarak deneyimlerin ve ilişkilerin bu sürece yön verdiğini ifade etmesi konuya ilişkin önemli açılımlar sunmaktadır. Annelik de zaman içinde deneyimlenen, değişebilen, farklı zamanlarda ve farklı koşullarda farklı haller alabilen bir süreçtir.

\section{Biyo-politik Söylem ve Annelik}

Anneliğin kurumsallaşması ve toplumsal yeniden üretim sürecinde önemli bir işleve sahip olduğunun düşünülmesi ile birlikte kadın bedeni; toplumsal ve politik söylemlerin odağında yer alan önemli bir mecraya dönüşmektedir. Toplumsal cinsiyeti tanımlayan ve onun üzerinden kadınlık ve erkeklik kimliğinin cisimleştiği beden, güç ve iktidar ilişkilerinin en somut alanını oluşturmaktadır. Bu iktidarlar; cinsellik, üreme, namus, toplumsal cinsiyet rollerinin inşası ve özellikle bütün bunların kesiştiği annelik olgusu üzerinden işlemektedir. Rothman $(1994 ; 2000)$ anneliğin sosyal inşasının nasıl gerçekleştiğini tartışırken; farklı ideolojik yapıların birbiri ile işbirliği içinde bu sürecin baş aktörü olduğunun ve aynı zamanda kadın bedenini şekillendiren üç farklı iktidar anlayışının nasıl işlediğinin analizini 
yapmaktadır. Patriarkal, teknoloji ve kapitalizm; kadın bedenini denetleyen, şekillendiren ve toplumsal ilişkiler içinde kadının konumunu belirleyen en önemli ideolojiler olarak tanımlamaktadır. Patriarka kadın bedeni, cinselliği, yeniden üretim sürecindeki rolü ve emeği üzerinde erkek egemenliğine işaret ederken, teknoloji ise kadın bedeni üzerinde tıbbi müdahaleler aracıllı̆ı ile doğrudan denetim kurmasına işaret etmektedir. Beden bir makine olarak görülmekte ve tıbbi müdahaleye açık hale getirilerek, çocuk sahibi olmanın birçok aşaması tıbbileştirilmektedir. Kapitalizm ise ataerkil ideoloji ve teknolojinin yardımıyla kendi sisteminin devamını sağlayacak, üretim ve tüketim ilişkileri içinde kârını maksimize edecek şekilde toplumsal cinsiyet eşitsizliğini yeniden üretmektedir. Bu üç ideoloji birbiri ile işbirliği içinde toplumdaki hiyerarşik güç yapılarını oluşturmakta, sosyal olayların anlamını belirlemekte ve statükonun devamında etkin rol almaktadır. Nitekim çocuk sahibi olmanın ataerkil kodlar tarafından kadın ve erkek için sahip olduğu anlamlar ve bu anlamların inşasında teknoloji ve kapitalizmin büründüğü roller önemli olduğu kadar çoğu kültürde çocuğun bakımından annelerin sorumlu tutulması ve ondan beklenilen roller o kadar önemli görülmektedir. Bu bakış açısı biyolojik ve sosyal anneliği, kapitalist, ataerkil ve sömürgeci üretim biçimlerini ve bunlara özgü hiyerarşik güç yapılarını tamamlayan ve koruyan spesifik üretim biçimleri olarak tanımlamaktadır (Neyer \& Bernardi, 2011, s. 7).

Ataerkil ideolojinin, teknoloji ve kapitalizme nasıl içkin hale gelerek sistemi yeniden üreten kutsal üçlüye dönüştügü, kadın bedeninin biyo-politikanın önemli konulardan biri olması ile açıklanabilir. Biyo-politikanın kapitalizmin etkili araçlarından biri olduğunu söyleyen Foucault'ya göre; çeşitli politikalar aracılığıyla bedenlerin üretim sürecine dâhil edilmesi ve nüfusun ekonomik faaliyetlere göre düzenlenmesi sağlanmaktadır (Foucault, 1993; Keskin, 2006; Foucault, 2001). Bedenler ve nüfuslar üzerinde nasıl politikalar yürütüldüğünü anlamamızı sağlayan biyo-politika; sağl1k-hastalık, doğum-kontrolü, üreme sağlı̆̆1, doğurganlık oranı, göç ve barınma gibi yaşamsal süreçler üzerinden toplumsal denetim geliştirir (Tekelioğlu, 1999, s. 152). Dolayısıyla çocuk doğurma bireysel gibi görünse de, kolektif yaşamın devamını sağladığı ve toplumun yeniden üretilmesinde önemli bir işleve sahip olduğu için biyo-politikanın da temel konularından birisi hâline gelmektedir. Bütün bu tartışmalar; üreme hakları, üreme teknolojilerinin kontrolü ve kadın bedeni üzerindeki denetim feminist hareketin de merkezinde yer almaktaydı. Özellikle beden siyasetinin önemli konusunu oluşturan üreme meselesi bireysel ya da sadece evlilikle ilişkilendirilen bir durum olmayıp aynı zamanda millî bir mesele olarak görülmektedir. Nira Yuval Davis'in "Cinsiyet ve Millet" adlı çalışması konuya ilişkin ayrıntılı bir analizi içererek, belli tarihsel koşullar içinde çocuk doğurabilecek durumda olan kadınlara kimi zaman teşviklerle, kimi zaman yaptırımlarla az ya da çok çocuk yapmalarının nasıl sağlandığını tartışmaktadır. Gündelik yaşam içinde uygulama alanı bulan ve somut politikaların konusu olan üç farklı söylemin bu duruma eşlik ettiğini söyleyen Davis'e göre (2010, s. 55) millî topluluğun nüfusunun korunmasını ve genişletilmesini millî çıkarlar için hayati olarak gören "iktidar olarak halk söylemi”; ilk söylemin aksine çocuk sayısının azaltılmasını, gelecekteki millî felaketleri önlemenin yolu olarak gören "Malthusçu söylem" ve köken sınıf açsından "uygun" olanları daha çok çocuk sahibi olmaya, diğerlerini de olmamaya teşvik ederek "millî stokların kalitesi”ni artırmaya yönelik "ojenist söylem" toplumda egemen olan üç söylemdir.

İlk söyleme göre halkın geleceği sürekli ne kadar iyi büyüdügüne bağlı olmakta ve kadınlar çocuk doğurmaya teşvik edilmektedir. Bu ulusun geleceğinin teminatı olarak görülmekte ve çeşitli ülkelerin hem annelik söylemlerine hem de doğurganlık politikalarına yansımaktadır. Malthusçu söylem ise doğurganlığın çok olduğu ülkelerde nüfusun kontrolsüzce artışını denetim altına alınmaya çalışmakta ve buna yönelik politikalar oluşturmaktadır. Devletin stratejik çıkarları olarak kabul edilen nüfusun izlenmesi ve yönetilmesi için halk sağlığı ve üreme sorunları önemli hâle gelmektedir (Pernigotti, 2010, 
s. 384). Aslında tarihî kayıtlar doğum kontrolüne yönelik yönetmelerin M.Ö 1550 yılına kadar dayandığını bize göstererek, tartışmanın toplumsal ve bireysel bağlamda her zaman var olduğunu anlamamızı sağlar. $\mathrm{Bu}$, önleyici anlayış ve nüfusun kontrol edilmesinin, binlerce yıldır bireylerin ve toplumların karşı karşıya kaldığı yaygın ve devam eden bir sorun olduğunu göstermektedir. Modern dünya içinde 20. yüzyılın ikinci yarısından sonra doğum kontrolü nüfus politikaları bağlamında gündeme gelmiş, ahlâki, dinî ve hukuki olarak mesele, birçok kesim tarafindan tartışıldığ 1 görülmektedir. Çin'de 1979'da başlayan tek çocuk politikası ve istemsiz kısırlaştırma, üremenin biyopolitik bir mesele olarak nasıl devlet kontrolünde örgütlendiğinin belirgin bir örneğini oluşturmaktadır (Cuomo, 2010, s.121). Bu uygulama 2013 y1lından sonra artan yaşlanan nüfus, cinsiyetler arası oransal dengesizlikler (kadın ve erkek nüfus oranı arasındaki farklılıklar) ve ekonomik büyümenin gerilemesinden dolayı gevşetilmiş ve daha sonra 2015 yılında yürürlükten kaldırılmıştır (Demir, 2016, s. 54). Japonya ve Almanya gibi ülkelerde azalan doğum oranları, demografik yaşlanma ve üretim sürecini yönetecek genç nüfusun yetersizliği ekonomistlerin konuya ilişkin duydukları endişe, doğurganlığ teşvik edici politikaların benimsenmesine neden olmuştur. Bazı ülkeler, kadınların çocuk sahibi olmalarını teşvik etmek için izin ve para desteği sağlayan programlar geliştirmiştir (Cuomo, 2010, s. 125).

Köken ve sınıf açısından "uygun" olanları daha çok çocuk sahibi olmaya, diğerlerini de olmamaya teşvik ederek "millî stokların kalitesi”ni artırmaya yönelik ojenist söylem ise niceliksel bir nüfus ile değil niteliksel bir nüfusla ilgilenir. Çünkü ulusun geleceği ve iktidarın gücünün sürekliliği için önemli bir etken olarak görülen bu durum aynı zamanda anneliğin politik söylemin hedefinde yer almasını sağlar. Kaliteli sağlıklı bebekler doğurup onları büyütmek kadınların en önemli görevleri arasında sayılır. Foucault'nun (1993, s. 31) “Cinselliğin Tarihi” adlı çalışmasında tartıştı̆̆ biyo-iktidar, sadece niceliksel bir nüfusla değil, doğum, yaşam süreleri, ölüm, doğurganlık, sağlık durumu, hastalıkların sıklığı beslenme ve konut gibi çok sayıda farklı etken ve bu etkenlerin yaşam kalitesi üzerindeki etkileri ile ilgilenmektedir. Ojenist söylem özellikle nüfusun kalitesini artırmaya yönelik 1rksal ve sınıfsal temelli bir politika güderek, doğurganlığı önleyebilmekte veya teşvik edebilmektedir. Davis'e göre (2010) tarihte ojenist söylemin en belirgin örneklerinden birini oluşturan Nazi Almanya'sından önce de ABD'nin bazı eyaletlerinde benimsenmiş ve kısırlaştırma yasaları çıkmıştır. Nazi Almanya'sında ise "Saf Ariler"in toplumsal ve ekonomik teşviklerle çoğalması sağlanmış buna karşın zekâ seviyesi düşük görülen ve toplumun ötekileri olarak kabul edilen "değersiz hayat"lar için zorla kısırlaştırmalar yapılmıştır. Nazi rejimi ile daha çok belirgin hâle gelen milliyetçi gelenekte annelik, bir ulusun ve ulusal kültürünün korunmasıyla ilişkilendirilmiş ve kadın olmak anne olmakla eşdeğer tutulmuştur. Bu bakış açısı daha sonra farklı ülkelerin ulusal-milliyetçi politikaları içinde önemli bir söyleme dönüşerek, kadına ve üremeye yönelik politikalarını da belirlemiştir (Lindgren, 2019, s. 6). Anneliğin sadece ırksal değil sınıfsal bir kimliğe de bürünmesini sağlayarak, beyaz orta sınıf bir annelik akımını ortaya çıkarmış, "beyaz üstünlükçü maternalizm” kavramsallaştırılmasıyla ulusun geleceği güvence altına alınmak istenmiştir. Örneğin Trump'ın politik söyleminde de yer bulan bu bakış açısı; ulusun geleceği, annelik ve geleneksel aile arasındaki ilişkiyi ön plana çıkartarak yeniden milliyetçimuhafazakâr bir zeminde politika yürütülmesini sağlamıştır. Daha somut bir ifade ile göçmen karşıtı ve Amerikan yanlısı "Amerika'yı Yeniden Büyük Yap" söylemi ile annelik; tekrardan beyaz orta sinıf bir temelde kurulmuş ve kapitalist sistemde ekonomik gelişme için bir çözüm oluşturabileceği düşünülmüşsür. Bu tartışmalar; kürtaj ekseninde yürütülerek, onun bir hak mı yoksa ulusun geleceği için toplumsal ve politik bir mesele mi olduğuyla da yakından ilişkilidir (Lindgren, 2019). Bir çatışma ve müzakere alanı olarak annelik her zaman politik söylemin odağında farklı alanlarda ve bağlamlarda tartışmaya açık bir konu olmuş, sadece nüfus politikalarında değil aynı zamanda toplumsal olaylarda üstlendikleri sorumluluk veya roller bağlamında da tartışılmıștır. Nitekim savaș karșıtı söylemde, barıș yanlısı politikalarda veya orduya ilişkin militarist söylemlerde annelik önemli bir araç olarak 
kullanılmış, anneliğe özgü düşünme biçimi burada ön plana çıkmıştır (Hughes, 2009; Ruddick, 2009; Aslan, 2009). Bu bağlamda farklı söylemlerin odağındaki annelik, bir uzlaşım ya da çatışma alanı olarak iktidarların temel meselelerinden biri olmaya devam etmektedir.

\section{SONUÇ}

Toplumsal, kültürel ve politik alanda üzerine anlamların ve mitlerin üretildiği annelik, kadınların gündelik yaşam pratiklerinin örgütleniş biçimini, toplumsal konumunu ve kamusal yaşamda yer alma (mama) biçimini etkilemektedir. Ataerkil heteronormatif değerlerin etkisi göz ardı edilmeden her dönemin ve toplumun kendine ait bir annelik söylemi olduğu ve bu söylemlerin kadınların normatif düzende yer alma biçimini etkilediği de ayrıca vurgulanmalıdır. Nitekim anneliğin içgüdüsel olduğu ve kadını "tanımlayan" ve "tamamlayan" en önemli özellik olduğu birçok kültürde ve toplumda benimsenen egemen bakış açısı olmuştur. Anneliğin içgüdüsel olduğu ve annelik sevgisi mitinin hemen hemen her toplumda kabul gören bir düşünce olmasına karşın her dönemin politik, kültürel ve ekonomik yapısı farklı annelik söylemlerinin gelişmesine kaynaklık etmiştir. Nitekim bunun en somut örneğini anneliğin belli sınırlar ve formlar etrafında deneyimlenmesine neden olan ve her dönemin hegemonik annelik söyleminin de gelişmesine kaynaklık eden "kutsal anne", "içgüdüsel annelik", "bilimsel anne", "mükemmel anne", "iyi anne", "ideal anne", "yoğun anne", "yeni annecilik", "empatik anne" gibi söylemler oluşturur. Bu annelik formları aynı zamanda hegemonik bir annelik formu çizerek yeni bir kadınlık ideali de yaratmaktadır.

Feminist bakış açısı için annelik, toplumsal cinsiyet eşitsizliklerini, cinsiyet rejimini, güç ve tahakküm ilişkilerini anlamak ve çözümlemek için önemli bir tartışma alanını oluşturmuştur. Bir yandan kadını baskılayan, toplumsal cinsiyet rollerini yeniden üreten, ataerkil ideolojiye güç ve tahakküm alanı yaratan annelik tartışmaları, öte yandan anneliği bir deneyim olarak gören ve kadına farklı bir bakış açısı kazandırdığını söyleyerek olumlayan yaklaşımlar hâlâ güncelliğini korumaktadır. Birinci çizgide yer alan düşünürler kadınlığın annelik üzerinden tanımlanmasına karşı çıkarak, kadını baskı altına alan ve kısıtlayan bir kurum olarak annelikten söz etmektedir. Aileye de eleştirel yaklaşan bu grup için kadının özgürlüğü annelik ve dolayısıyla kadınlık rollerinden siyrılmasıla mümkün olup, üreme teknolojilerinin kontrolü ve çalışan kadın miti önemli bir söyleme dönüşmektedir. Öte yandan ikinci çizgide yer alan feminist yaklaşım içinde güçlendirilmiş annelik söylemleri benimsenerek, annelik deneyimi, öznellik ve özerklik ve kadına ait farklılıkların olumlanması gibi meseleler ele alınır. ataerkil ideolojinin etkisinde şekillenen kurumsal baskıdan sıyrılmanın olanaklılığı ile birlikte anneliğin kadın için daha özgürleştirici bir deneyime dönüşebileceği de tartışılmaktadır. Anneliğin tekil bir forma indirgenerek açıklanamayacağı, genelgeçer özcü ve evrenselleştirici bir formdan bahsedilemeyeceği fikrinin de bu tartışmalara eklemlenmesi ile birlikte konu çok boyutlu bir hâl almışa benzemektedir.

Annelik rolü üzerinden ideal kadının sınırları belirlenerek, cinsiyet rejimine içkin olan iktidar ilişkilerinin yeniden üretilmekte ve ataerkil normatif düzenin sürekliği de sağlanmaktadır. Bu bağlamda anneliğin sosyal yapısını açığa çıkarılmasına olanak tanıyan "söylem" toplumdaki iktidar ve güç ilişkilerinin cinsiyet temelinde açıklanmasına da olanak tanır. Egemen annelik söylemleri; sosyal yaşamı, politik bakış açısını, güç ve tahakküm ilişkilerini belirleyerek, bu tahakküm ilişkilerinin doğrudan kadının yaşam süreçleri üzerinden işlemesini de sağlamaktadır. Annelik dolayımıyla kadın bedeni "siyasal" ve "ulusal" bir mesele olarak da ele alınmakta, biyo-politikanın da önemli bir alanına dönüşmektedir. anneliğin sağlamıştır. Kapitalizm, teknoloji ve ataerkil ideolojinin işbirliği ile yeniden tanımlanan ve sosyal düzenlemeye maruz kalan annelik, önemli kamusal mesele olarak da ele alınmaktadır. Nitekim nüfus politikalarının kadın bedeni üzerinden doğrudan yürütülmesi; her dönemin buna bağlı gelişen uygulamalarının olması ve günümüzde siyasal iktidarların söyleminde yine annelik 
ve kürtaj meselelerinin olması biyo-politikanın güncel örneklerini oluşturur. Bu bağlamda annelik, siyasal sistemler için önemli retorik güce veya iktidar kaynağına da dönüşmektedir.

\section{KAYNAKÇA}

Allan, J. (2004). "Mother Blaming: A Covert Practice İn Therapeutic İntervention". Australian Social Work, (57), 57-70. https://doi.org/10.1111/j.0312-407X.2003.00114.x.

Allen, A. T. (2005). Feminism and Motherhood in Western Europe, 1890- 1970. New York: Palgrave Macmillan.

Arendell, T. (2000). "Conceiving and Investigating Motherhood: The Decade's Scholarship". Journal of Marriage and the Family, 62(4), 1192-1207, https://doi.org/10.1111/j.17413737.2000.01192.x.

Aslan, Ö. (2009). "Kaçınılmaz Ölüm"ün Girdabındaki Annelik". Kültür ve Siyasette Feminist Yaklaşımlar, İstanbul: bgst Yayınları, 75-98.

Badinter, E. (1992). Annelik Sevgisi: 17. Yüzyıldan Günümüze Bir Duygunun Tarihi. Çelik K. (Çev.) İstanbul: AFA Yayınları.

Bora, A. (2005). Kadınların Sinıfi. İstanbul: İletişim yayınları.

Bozok, M. (2018). “Toplumsal Cinsiyet ve Aile”. içinde N. Oktik \& H. Ünal Reşitoğlu (Ed.), Aileyi Anlamak, Ankara: Siyasal Yayınevi, 101-114.

Butler, J. (2013). Bela Bedenler. C. Çakırlar, Z. Direk (çev.), İstanbul: Pinhan Yayıncılık.

Chodorow, N. J. (1999). The Reproduction of Mothering: Psychoanalysis and the Sociology of Gender. California: Univ of California Press.

Collins, P. H. (1994). "Shifting the Center; Race, Class, And Femınist Theorizing About Motherhood". In E. N. Glenn, G. Chang \& L. R. Forcey (Eds.), Mothering Ideology, Experience, And Agency, (pp.139-157), London, Newyork: Routledge.

Cuomo, A. (2010). "Birth Control”. In A. O'reilly (Ed.). Encyclopedia of Motherhood,, (pp. 488-492) Sage Publications.

Çelik, H. \& Ekşi H. (2008). “Söylem Analizi”. Marmara Üniversitesi Eğitim Bilimleri Dergisi, 1(27), 99-117.

Davis ,N. Y. (2010). Cinsiyet ve Millet, Ayşin Bektaş (Çev). İstanbul: İletişim Yayınları.

Demir, O. (2016). "Nüfus Politikaları ve Çin, Fransa ve Türkiye Örneklerinin Değerlendirilmesi". Social Sciences, 11(1), 41-61, http://dx.doi.org/10.12739/NWSA.2016.11.1.3C0137.

Donovan, J. (2007). Feminist Teori. A. Bora ve d. (Çev.), İstanbul: İletişim Yayınevi.

Douglas, S. \& Michae 1s, M. (2004). The Mommy Myth, the Idealization of Motherhood and How It Has Undermined Women, New York: Free Press.

Dow, D. M. (2016). Integrated Motherhood: Beyond Hegemonic Ideologies of Motherhood, Journal of Marriage and Family, (78), pp. 180-196 , DOI:10.1111/jomf.12264

Durudoğan, H. (2007). “Unes Femmes: Kristeva, Psikanaliz ve Kadın”. İçinde Z. Direk (Edt.), Cinsiyetli Olmak: Sosyal Bilimlere Feminist Bakışlar, İstanbul: Yapı Kredi Yayınları.

Firestone, S. (1993). Cinselliğin Diyalektiği. Y. Salman (Çev), İstanbul: Payel Yayınları. 
Forcey, L. R. (1994). "Feminist Perspective on Mothering and Peace". In E. N. Glenn, G. Chang \& L. R. Forcey (Eds.), Mothering Ideology, Experience, And Agency, (pp. 355-377), London: Routledge Company.

Foucault, M. (1993). Cinselliğin Tarihi-I. H. Tufan (Çev.), Afa Yayınları: İstanbul.

Foucault, M. (2001). Toplumu Savunmak Gerekir, Şehsuvar Aktaş (Çev.) Yapı Kredi Yayınları: İstanbul.

Garwood, E. (2014). "Regulating Motherhood: a Foucauldian Analysis of the Social Construction of the Mother". The New Birmingham Review, 1(1), 19-28.

Gerson, K. (2010). The Unfinished Revolution How a New Generation Is Reshaping Family, Work and Gender in America. Oxford, NewYork: Oxford University Press.

Glenn, E. N. (1994). "Social Constructions of Mothering: A Thematic Overview". In E. N. Glenn, G. Chang \& L. R. Forcey (Eds.), Mothering Ideology, Experience, And Agency,(pp. 1-33), London: Routledge Company.

Hays, S. (1996). The Cultural Contradictions Of Motherhood. New Haven, London: Yale University Press.

Hançer, A. (2018). “Toplumsal Cinsiyet Öznesi Olarak Kadının "Annelik” Kimliğine Eleştirel Bir Bakış”. Akdeniz Kadın Çalışmaları ve Toplumsal Cinsiyet Dergisi, 1(2), 177-202.

Henderson, A. C., Harmon, S. M. \& Houser, J. (2010). "A new State of Surveillance? An Application of Michel Foucault to Modern Motherhood". Surveillance \& Society 7(3/4), 231-247.

Hochschild, A. R., \& Machung, A. (1989). The Second Shift: Working Parents and the Revolution at Home. New York: Penguin Books.

Hughes, N. S. (2009). “Anneliğe Özgü Düşünme Biçimi ve Savaş Politikaları”. Kültür ve Siyasette Feminist Yaklaşımlar, G. Türkoğlu (Çev.), İstanbul: bgst Yayınları, 11-20.

Irigaray, L. (2000). Nietzsche’nin Deniz Aşığı. İ. Yerguz (Çev.), İstanbul: Kabalcı Yayınevi.

Johnston, D. \& Swanson D. (2003). "Invisible Mothers: A Content Analysis of Motherhood Ideologies and Myths in Magazines". Sex Roles, 49(1/2), 21-33.

Keskin, F. (2005). “Özne ve İktidar”, içinde Ferda Keskin (Yay. Haz.), Michel Foucault, Seçme Yazllar-2, İstanbul: Ayrıntı Yayınları.

Lindgren, Y. (2019). “Trump's Angry White Women: Motherhood, Nationalism, And Abortion". Working Draft-Hofstra Law Review, (47),1-32, https://dx.doi.org/10.2139/ssrn.3386416

Mattingly, J. M. \& Bianchi S. M. (2003). "Gender Differences in the Quantity And Quality of Free Time: the U.S. Experience”. Social Forces, 81(3), 999-1030.

Millet, K. (1989). Cinsel Politika, S. Selvi (Çev.), İstanbul: Payel Yayınları.

Moore, H. L. (2003). "Mothering and Social Responsibilities in a Cross-Cultural Perspective". In E. B. Silva (Edt.), Good Enough Mothering, (pp. 58-759, London: Routledge

Neyer, G., Bernardi, L. (2011). Feminist Perspectives on Motherhood and Reproduction, Historical Social Research, 36(2), pp.162-176, https://doi.org/10.12759/hsr.36.2011.2.162-176

O’Relilly, A. \& Porter, M. (2005). “Introduction”. In M. Porter, P. Short, A. O'Reilly (Eds.) Motherhood Power And Oppression, Toronto: Women's Press. 
Pernigotti, E. (2010). "Family Planning”. In A. O'reilly (Ed.), Encyclopedia of Motherhood, (pp. 383388), California: Sage Publications

Porter, M. (2010). "History of Motherhood: 1900 to Present". In A. O'reilly (Ed.), Encyclopedia of Motherhood, (pp. 504-507), California: Sage Publications.

Raley, S., Bianchi, M. S. \& Wang W. (2012). "When Do Fathers Care? Mothers' Economic Contribution and Fathers' Involvement in Child Care". American Journal of Sociology, 117(5), 1422-1459. doi:10.1086/663354.

Rich, A. (1995). Of Woman Born: Motherhood As an Experience and Institution. New York: W. W. Norton \& Company.

Rothman, B. K. (1994). "Mothers and Fathers: Ideology in a Patriarchal Society". In E. N. Glenn, G. Chang \& L. R. Forcey (Eds.), Mothering Ideology, Experience, And Agency, (pp. 139-157), London, Newyork: Routledge.

Rothman, B. K. (2000). Recreating Motherhood. New York: Rutgers University Press.

Ruddick, S. (1980). Maternal Thinking. Feminist Studies, 6(2), 342-367.

Ruddick, S. (2009). "Barış Kadını: Feminist Bir Yorum", Kültür ve Siyasette Feminist Yaklaşımlar, A. Günaydın (Çev.), İstanbul: bgst Yayınları, 21-48.

Silva, E. B. (2003). "Introduction", In E. B. Silva (Ed.), Good Enough Mothering?: Feminist Perspectives on Lone Mothering, (pp. 1-19), London, Newyork: Routledge.

Smart, C. (2003). "Deconstructing Motherhood". Good Enough Mothering?: Feminist Perspectives on Lone Mothering, (pp. 37-57), London London, Newyork: Routledge.

Tekelioğlu, O. (1999). Michel Foucault ve Sosyolojisi. Bağlam Yayınevi: İstanbul.

Thurer, S. L. (1994). Myths of Motherhood, Boston: Houghton Mifflin.

Trevino, M. B. (2010). "History of Motherhood: 2000 b.c.e. to 1000 c.e.", In A. O'reilly (Ed.), Encyclopedia of Motherhood, (pp. 488-492), California: Sage Publications.

Uzogara, E. E. (2015). "Perceptions of Motherhood: Differences among Racial Majority and Minority Women". International Journal of Culture and History, 1(1), 67-70, doi: 10.18178/ijch.2015.1.1.012.

Vincent, C. (2010). "The Sociology of Mothering". In M. W. Apple, S. J. Ball \& L. A. Gandin (Eds), The Routledge International Handbook of the Sociology of Education, (pp. 109-120). Routledge. 